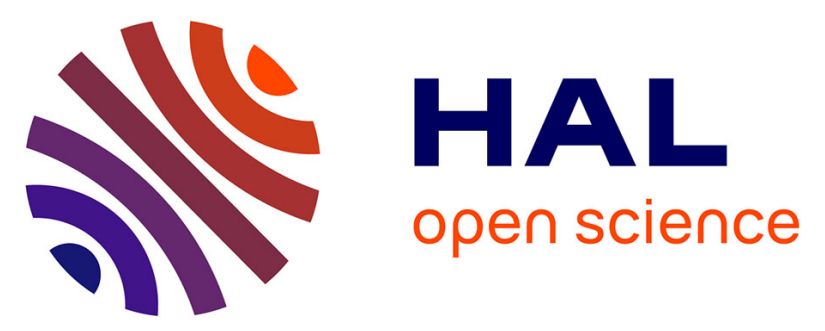

\title{
Soil moisture retrievals at L-band using a two-step inversion approach (COSMOS/NAFE'05 Experiment)
}

Khaldoun Saleh, Yann H. Kerr, Philippe Richaume, Maria-José Escorihuela, R. Panciera, S. Delwart, Gérard Boulet, Philippe Maisongrande, J. P. Walker, P. Wursteisen, et al.

\section{To cite this version:}

Khaldoun Saleh, Yann H. Kerr, Philippe Richaume, Maria-José Escorihuela, R. Panciera, et al.. Soil moisture retrievals at L-band using a two-step inversion approach (COSMOS/NAFE'05 Experiment). Remote Sensing of Environment, 2009, 113 (6), pp.1304-1312. 10.1016/j.rse.2009.02.013 . ird-00389586v2

\section{HAL Id: ird-00389586 \\ https://hal.ird.fr/ird-00389586v2}

Submitted on 29 May 2009

HAL is a multi-disciplinary open access archive for the deposit and dissemination of scientific research documents, whether they are published or not. The documents may come from teaching and research institutions in France or abroad, or from public or private research centers.
L'archive ouverte pluridisciplinaire HAL, est destinée au dépôt et à la diffusion de documents scientifiques de niveau recherche, publiés ou non, émanant des établissements d'enseignement et de recherche français ou étrangers, des laboratoires publics ou privés. 
Provided for non-commercial research and education use. Not for reproduction, distribution or commercial use.

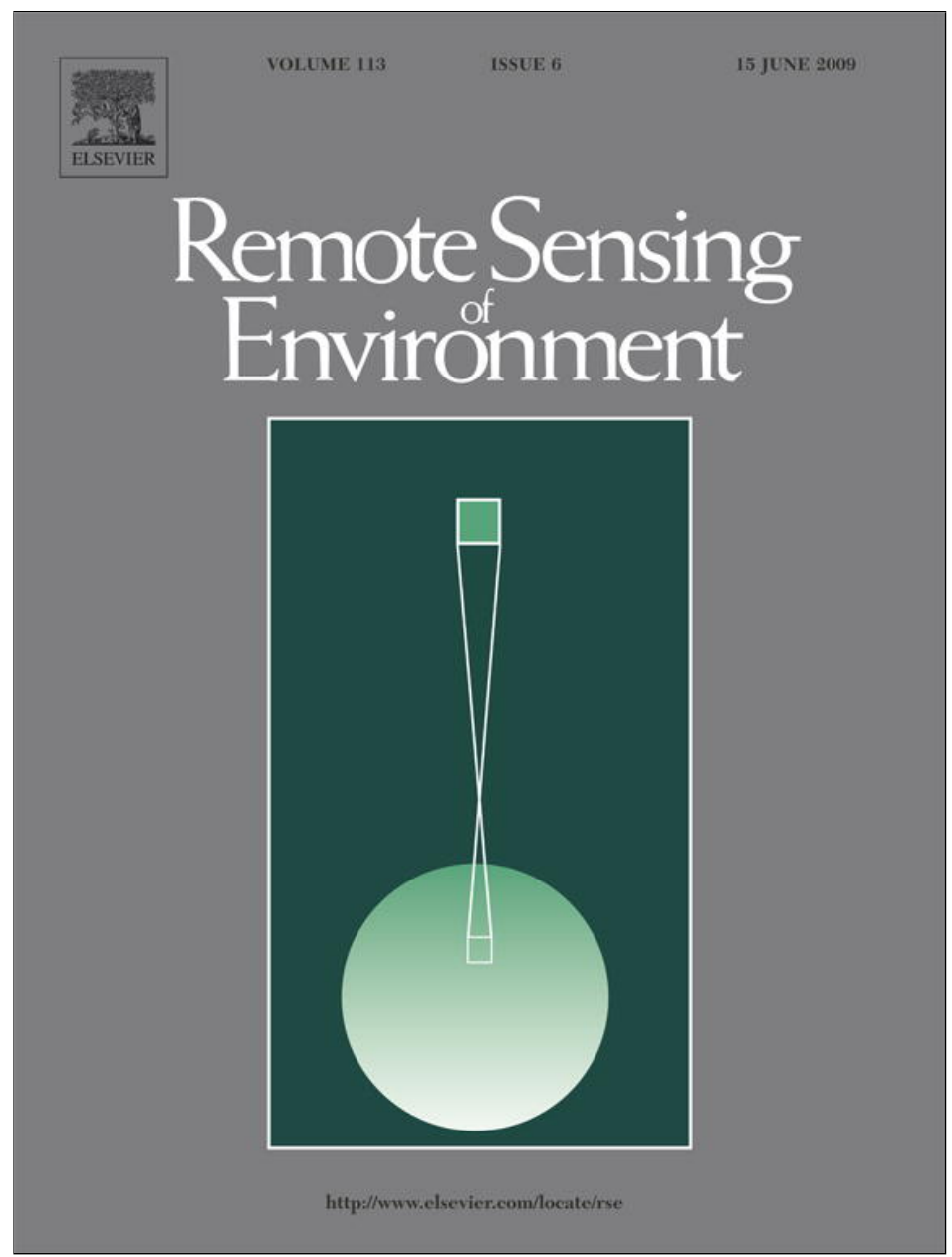

This article appeared in a journal published by Elsevier. The attached copy is furnished to the author for internal non-commercial research and education use, including for instruction at the authors institution and sharing with colleagues.

Other uses, including reproduction and distribution, or selling or licensing copies, or posting to personal, institutional or third party websites are prohibited.

In most cases authors are permitted to post their version of the article (e.g. in Word or Tex form) to their personal website or institutional repository. Authors requiring further information regarding Elsevier's archiving and manuscript policies are encouraged to visit:

http://www.elsevier.com/copyright 


\title{
Soil moisture retrievals at L-band using a two-step inversion approach (COSMOS/NAFE'05 Experiment)
}

\author{
K. Saleh ${ }^{\mathrm{a}, *}$, Y.H. Kerr ${ }^{\mathrm{b}}$, P. Richaume ${ }^{\mathrm{b}}$, M.J. Escorihuela ${ }^{\mathrm{b}}$, R. Panciera ${ }^{\mathrm{c}}$, S. Delwart ${ }^{\mathrm{d}}$, G. Boulet $^{\mathrm{b}}$, \\ P. Maisongrande ${ }^{\text {b }}$, J.P. Walker ${ }^{c}$, P. Wursteisen ${ }^{\mathrm{d}}$, J.P. Wigneron ${ }^{\mathrm{e}}$ \\ a Department of Geography, University of Cambridge, UK \\ b CESBIO, Toulouse, France \\ c Department of Civil and Environmental Engineering, University of Melbourne, Australia \\ d ESTEC-ESA, The Netherlands \\ e EPHYSE-INRA, Bordeaux, France
}

\section{A R T I C L E I N F O}

\section{Article history:}

Received 13 October 2008

Received in revised form 12 February 2009

Accepted 14 February 2009

\section{Keywords:}

SMOS

Soil moisture

L-band

Radiometry

Soil roughness

COSMOS

NAFE

\begin{abstract}
A B S T R A C T
COSMOS (Campaign for validating the Operation of Soil Moisture and Ocean Salinity), and NAFE (National Airborne Field Experiment) were two airborne campaigns held in the Goulburn River catchment (Australia) at the end of 2005. These airborne measurements are being used as benchmark data sets for validating the SMOS (Soil Moisture and Ocean Salinity) ground segment processor over prairies and crops. This paper presents results of soil moisture inversions and brightness temperature simulations at different resolutions from dual-polarisation and multi-angular L-band $(1.4 \mathrm{GHz})$ measurements obtained from two independent radiometers. The aim of the paper is to provide a method that could overcome the limitations of unknown surface roughness for soil moisture retrievals from L-band data. For that purpose, a two-step approach is proposed for areas with low to moderate vegetation. Firstly, a two-parameter inversion of surface roughness and optical depth is used to obtain a roughness correction dependent on land use only. This step is conducted over small areas with known soil moisture. Such roughness correction is then used in the second step, where soil moisture and optical depth are retrieved over larger areas including mixed pixels. This approach produces soil moisture retrievals with root mean square errors between $0.034 \mathrm{~m}^{3} \mathrm{~m}^{-3}$ and $0.054 \mathrm{~m}^{3} \mathrm{~m}^{-3}$ over crops, prairies, and mixtures of these two land uses at different resolutions.
\end{abstract}

(c) 2009 Elsevier Inc. All rights reserved.

\section{Introduction}

The European Space Agency will launch the SMOS (Soil Moisture and Ocean Salinity) satellite during the summer of 2009. The generation of land products from SMOS brightness temperature $(T B)$ measurements relies on the inversion of the microwave forward model L-MEB (L-band Microwave model of the Biosphere; Wigneron et al., 2007; Kerr, Waldteufel et al., 2006). The L-MEB model assembles a set of equations describing the emission and scattering of the surface, vegetation and atmosphere at L-band $(1.4 \mathrm{GHz})$. The optimisation of L-MEB for different surfaces has been addressed by numerous studies over the last twenty years, most of them based on the analysis of ground-based L-band data. This paper is part of the COSMOS ESA study (Saleh et al., 2007a), designed to test L-MEB over crops and prairies using airborne L-band

\footnotetext{
* Corresponding author. Department of Geography, University of Cambridge, Downing Place, Cambridge CB2 3EN, UK.

E-mail address: kauzar.saleh@uv.es (K. Saleh).
}

data from the COSMOS/NAFE campaign (Panciera et al., 2008). While the main focus of the COSMOS study is to address open issues regarding the microwave modelling of land surfaces, dedicated campaigns are planned with specific focus on the validation of land products (Delwart et al., 2008). A key aspect concerns modelling of the soil emission, as the relationship between the soil emissivity and the surface soil moisture $(S M)$ at L-band is influenced by the dielectric profile at and near the surface as well as by the effective temperature. As a consequence, a sitespecific characterisation of the soil emission, which is usually represented by the roughness parameters $H_{\mathrm{R}}$ (Choudhury et al., 1979), and $N_{\mathrm{R}, \mathrm{p}}$ (Wang et al.,1983), is often conducted in soil moisture retrieval studies. These parameters are used to express the ratio between the reflectivity of a rough and a smooth surface through the exponential term exp $\left(-H_{\mathrm{R}} \cdot \cos ^{N_{R, p}}(\theta)\right)$, with $N_{\mathrm{R}, \mathrm{p}}$ being dependent on the measured polarisation. The main concern regarding roughness is its effect on soil moisture retrievals. If roughness is underestimated so will be the modelled surface emissivity, and the retrieved soil moisture will be underestimated as a result.

While several studies have addressed the generalisation of $H_{\mathrm{R}}$ as a function of the measured surface roughness (Mo \& Schmugge, 1987; 
Wigneron et al., 2001) a global roughness correction is not available, and alternative methods need to be developed should roughness also play a role at satellite low-resolution scales $(40 \mathrm{~km})$. This is of great importance as rather high microwave roughness $\left(H_{R}>0.3\right)$ was measured in experimental plots observed by ground radiometers at L-band (Escorihuela et al., 2007; Saleh et al., 2007b; Wigneron et al., 2007). These values are comparable to estimates from satellite data at higher microwave frequencies (Pellarin et al., 2006), more sensitive to surface roughness. Therefore, L-band roughness could play an important role in soil moisture retrievals from satellite, and currently it is unclear whether its effect will be reduced by the lower spatial resolution and lower radiometric sensitivity of satellite radiometers compared to ground radiometers.

A study on the validation of the L-MEB model from high-resolution airborne data of the COSMOS/NAFE campaign was recently completed by Panciera et al. (2009). The study suggested that while the vegetation parameters available in the literature are generally well suited to simulate the vegetation optical depth $\left(\tau_{\mathrm{NAD}}\right)$, knowledge of soil roughness is essential. The authors estimated $H_{\mathrm{R}}$ to be dependent of soil moisture, with $H_{\mathrm{R}} \sim 1$ for clay soils and soil moisture $0.20 \mathrm{~m}^{3} \mathrm{~m}^{-3}$.
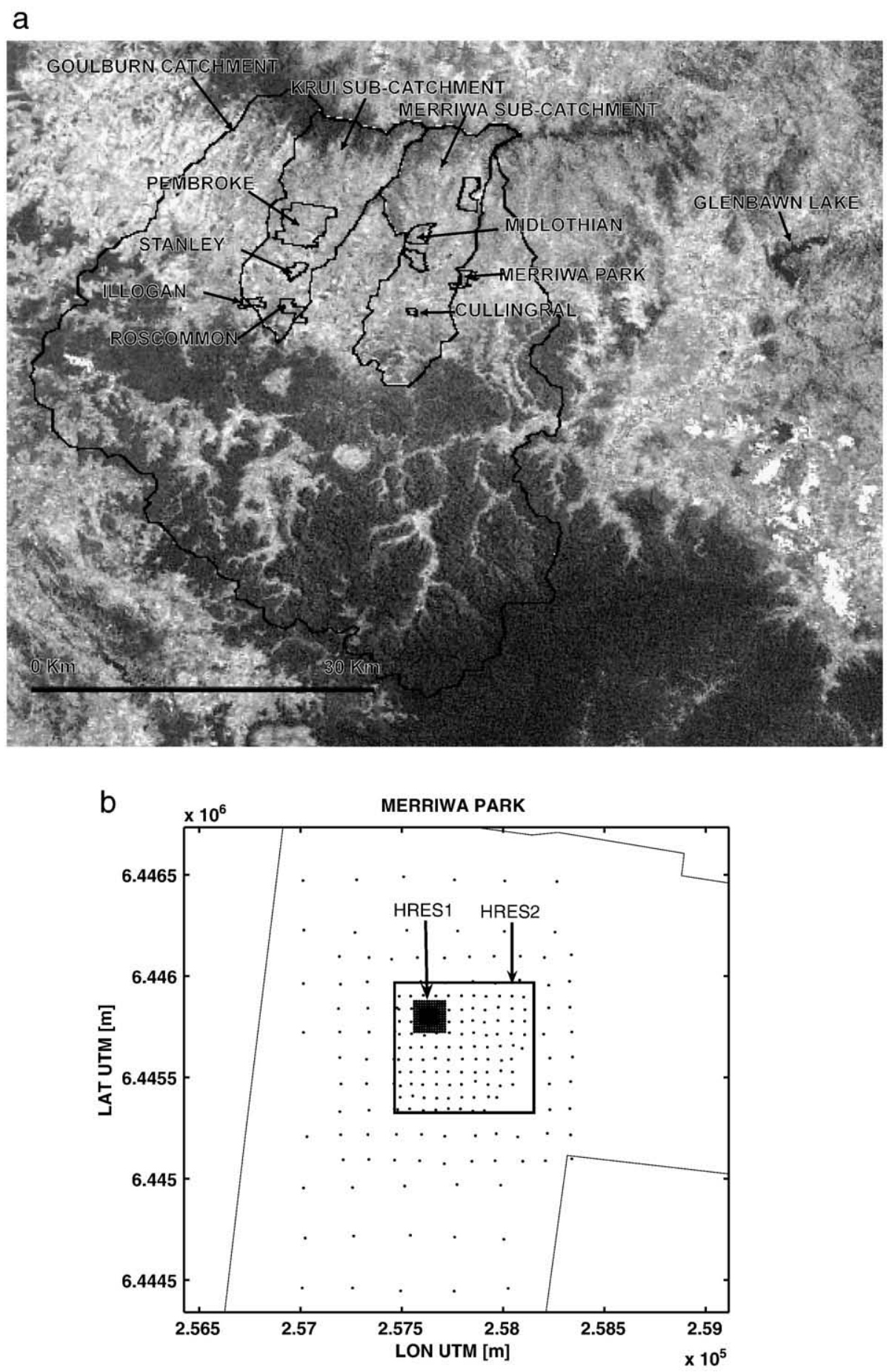

Fig. 1. (a) The Goulburn River catchment experimental site: catchments, focus farms, and calibration lake, (b) Example of soil moisture sampling points at Merriwa Park (black dots), high-resolution soil moisture sampling area used for model calibration (HRES1), and extended area HRES2 used for model validation. 
In order to determine soil roughness, the authors conducted site-specific retrievals of $H_{R}$ requiring measurements of the soil moisture and vegetation water content.

In this paper we propose an alternative method to retrieve soil moisture in areas of unknown roughness and unknown vegetation water content with a view on operational applications. The method is based on a two-step two-parameter (2-P) inversion of the L-MEB model. First, $H_{R}$ and the microwave optical depth at nadir are retrieved in small and homogeneous areas of known soil moisture, and a roughness correction dependent on land use only is obtained (either for crops or for prairies). This roughness correction is then applied to 2-P retrievals of soil moisture and optical depth beyond the calibration area, and it is shown to be valid at different footprint resolutions including mixtures of land use across the whole soil moisture range. The two-step inversion method was previously applied to ground-based L-band measurements in a natural grass plot (Saleh et al., 2007b), where the 2-P inversion of $\tau_{\mathrm{NAD}}$ and $H_{\mathrm{R}}$ provided the best approach to retrieve soil moisture in a surface with organic debris. However, the approach had not been tested before using L-band measurements acquired at different resolutions and over different surfaces. To simulate the brightness temperatures of the surface, the study uses the SMOS ground processor breadboards. The SMOS breadboards are a set of routines using the same microwave model and parameterisations included in the SMOS Level 2 processor (Kerr et al., 2006), as well as the same rationale concerning the aggregation of simulated brightness temperatures over mixed pixels.

This paper starts with a description of the experimental area and data sets, followed by the methodology involved in processing airborne passive microwave measurements. The parameter retrieval method is described afterwards, followed by the discussion of soil moisture retrievals over crops, grass, and mixed land uses at different resolutions.

\section{Data set}

\subsection{The Goulburn River catchment}

The area of study is within the Goulburn River catchment (31.77 S to $32.85 \mathrm{~S}, 149.67 \mathrm{E}$ to $150.60 \mathrm{E}$ ) in New South Wales (Australia). This is a semi-arid region of approximately $6540 \mathrm{~km}^{2}$, with a central plateau dedicated to crop growth and grazing. The climate of the catchment is sub-humid to temperate, with annual rainfall of approximately $700 \mathrm{~mm}$ in 2005 (Rudiger et al., 2007). The experimental area during COSMOS/NAFE covered four focus farms in the Krui river sub-catchment, on the northwest side $\left(562 \mathrm{~km}^{2}\right)$, and four in the Merriwa river sub-catchment, on the northeast side $\left(651 \mathrm{~km}^{2}\right)$. A location map is provided in Fig. 1a, while Table 1 summarises the characteristics of each focus farm used for this study in terms of soil type and vegetation. Radiometer calibration tests during COSMOS/ NAFE took place at the Glenbawn Lake (Fig. 1a), east of the Goulburn River catchment, and also at the Alexandrina Lake near Adelaide $\left(35^{\circ} 25^{\prime} \mathrm{S} 139^{\circ} 07^{\prime} \mathrm{E}\right)$ for COSMOS flights.

Table 1

Focus farms at the Goulburn river catchment.

\begin{tabular}{llll}
\hline Farm & Land use & $\begin{array}{l}\text { Sand }(s), \\
\text { clay }(c) \text { fraction }\end{array}$ & $\begin{array}{c}\text { LAI-range }\left(\mathrm{m}^{2} \mathrm{~m}^{-2}\right) \\
\text { from MODIS } 250 \mathrm{~m}\end{array}$ \\
\hline Pembroke (11) & Wheat & $s=0.06, c=0.7$ & $2-2.5$ \\
Stanley (12) & Grazing & $s=0.06, c=0.6$ & $1.5-2$ \\
Illogan (13) & Barley, oats & $s=0.2, c=0.3$ & $1.5-2.5$ \\
Roscommon (14) & Grazing & $s=0.7, c=0.1$ & $1.5-2$ \\
Midlothian (22) & Grazing & $s=0.1, c=0.7$ & $1.5-2$ \\
Merriwa Park (23) & Wheat & $s=0.2, c=0.4$ & $1.5-2$ \\
Cullingral (24) & Wheat & $s=0.2, c=0.4$ & $1-2$ \\
\hline
\end{tabular}

Table 2

Summary of flights supported by intensive ground sampling used for this study.

\begin{tabular}{llllllc}
\hline Label & Sensor & Configuration & $\begin{array}{l}\text { Resolution } \\
-3 \mathrm{~dB} \text { nadir }\end{array}$ & $\begin{array}{l}\text { Land } \\
\text { use }\end{array}$ & $\begin{array}{l}\text { Number } \\
\text { of farms }\end{array}$ & $\begin{array}{c}\text { Number } \\
\text { of flights }\end{array}$ \\
\hline AT-EMIRAD & EMIRAD & Along-track & $350 \mathrm{~m}$ & Crop & 3 & 3 \\
AT-EMIRAD & EMIRAD & Along-track & $350 \mathrm{~m}$ & Grass & 3 & 3 \\
AT-PLMR & PLMR & Along-track & $250 \mathrm{~m}$ & Crop & 2 & 4 \\
CT1-PLMR & PLMR & Across-track & $60 \mathrm{~m}$ & Crop & 3 & 10 \\
CT1-PLMR & PLMR & Across-track & $60 \mathrm{~m}$ & Grass & 3 & 10 \\
CT2-PLMR & PLMR & Across-track & $250 \mathrm{~m}$ & Grass & 3 & 9 \\
\hline
\end{tabular}

\subsection{Airborne measurements}

\subsubsection{EMIRAD}

COSMOS flights used the EMIRAD fully polarimetric radiometer (Rotbøl et al., 2003) onboard an Aero Commander 500S Shrike aircraft. Onboard instrumentation also included an inertial navigation unit combined with a GPS receiver for aircraft attitude and position recording. Two Potter horn antennas were installed along-track (AT), one facing nadir ( $37.6^{\circ}$ half-power beam-width), the other at an angle of $40^{\circ}$ towards the rear of the aircraft ( $30.6^{\circ}$ half-power beam-width). Microwave data were produced at $8 \mathrm{~ms}$ integration time. Baseline calibration was performed in the laboratory using a Standard Noise Generator (LN2) and an internal hot load, as well as in the aircraft to account for antenna cable losses. Once airborne, internal calibrations were performed to adjust the gain and noise temperature for each measurement. The measured radiometric performance was $0.9 \mathrm{~K}$ for $8 \mathrm{~ms}$ integration time and $300 \mathrm{~K}$ input temperature. The whole EMIRAD data set covered six weeks of data (14 November-9 December 2005), and approximately $30 \mathrm{~h}$ of flight time. However, in this study we only made use of EMIRAD flights supported by ground soil moisture measurements at high resolution ( 3 flights over grass at Stanley, Roscommon and Midlothian, and 3 flights over crops at Pembroke, Illogan and Merriwa Park, Table 2). These flights were single lines performed over each farm with a nominal footprint size of $350 \mathrm{~m}$ conducted in the early morning between 15 November and 23 November. Potential instrumental errors in the rear antenna at horizontal polarisation are being investigated and have been discarded for this study. Therefore, the analysis of EMIRAD data is based on nadir acquisitions at horizontal $(\mathrm{H})$ and vertical (V) polarisation, and 40-degree observations at $\mathrm{V}$ polarisation. As a result EMIRAD data were not used to retrieve soil moisture but instead they were used to either compare forward model simulations to brightness temperature measurements, or for the retrieval of optical depth. Finally, infrared measurements at nadir were obtained concurrently to L-band data. For that purpose a Heimann KT15 sensor was used (full beam-width is $4^{\circ}$ ).

\subsubsection{PLMR}

The Polarimetric L-band Multibeam Radiometer (PLMR) was installed onboard an Eco-Dimonna aircraft. The radiometer measured horizontally and vertically polarised radiation at six angles of incidence $\left(+/-7^{\circ},+/-22^{\circ},+/-38.5^{\circ}\right)$ through an antenna patch array with half-power beam-width between $13^{\circ}$ and $16.5^{\circ}$. Modifications to the manufacturer calibration were based on external measurements of the sky brightness temperature (cold point) and that of a microwave absorbent (warm point). These measurements were performed at ground level before and after each flight. Further details are available in Panciera et al. (2008), where the complete PLMR flight plan can be found. The PLMR data set covered four weeks (30 Oct-25 Nov 2005), with the last two weeks overlapping with EMIRAD flights. The flights considered for this study are also summarised in Table 2. These included six flights in the along-track direction (AT-PLMR) with nominal nadir footprint of $250 \mathrm{~m}$ at $-3 \mathrm{~dB}$; flights in the across-track direction with a nominal footprint size at nadir equal to $60 \mathrm{~m}$ (CT1- 
PLMR), and $250 \mathrm{~m}$ (CT2-PLMR), all supported once a week by ground sampling at each farm. PLMR data were used to perform retrievals at all farms except at Illogan, where the number of multi-angular footprints was considered to be insufficient.

\subsection{Ground measurements and ancillary data}

The ground data used in this study is a subset of the COSMOS/ NAFE'05 data set (Panciera et al., 2008) and it comprises the following measurements:

- Soil moisture. Surface soil moisture (SM) measurements were obtained from mobile probes (HydraProbe and ThetaProbe). These are capacitance probes with sampling depth of approximately $6 \mathrm{~cm}$. Sampling spatial resolutions varied between $6 \mathrm{~m}$ and $500 \mathrm{~m}$, and for this study an area of approximately $1 \mathrm{~km}^{2}$ within each farm labelled as HRES2 was considered (Fig. 1b). A smaller area of about $150 \mathrm{~m} \times 150 \mathrm{~m}$ within HRES2 included 6-m and 12-m sampling only, and we will refer to it as HRES1 (Fig. 1b). All flights analysed in this study were supported by soil moisture samples both in the HRES1 and HRES2 areas. Soil moisture sampling took approximately $5 \mathrm{~h}$, while the duration of flights varied between $15 \mathrm{~min}$ and $2 \mathrm{~h}$. However, we found that temporal variations of soil moisture were less significant than spatial ones (not shown), and the whole sampling period was used to calculate ground-truth soil moistures.

- Soil temperature. Surface temperature $\left(T_{\text {sfce }}\right)$ at $2.5 \mathrm{~cm}$ depth was obtained from temperature monitoring stations located within each farm. Deep soil temperature $\left(T_{\text {depth }}\right)$ was obtained from one station in the Krui area measuring soil temperature at $60-\mathrm{cm}$ depth.

- Soil texture. Soil texture was estimated from 30-cm depth soil samples obtained in the HRES1 area at each focus farm, with the exception of Cullingral and Roscommon where texture was obtained from soil samples within $5 \mathrm{~cm}$ of the surface.

In addition, the following ancillary maps were used to characterise the surface land use and topography:

- Land use. A Landsat 5TM-derived land use supervised classification was used to determine land uses covered by each footprint. The classification was for October 2005 and the resolution was $25 \mathrm{~m}$. The classification provided thirteen categories, grouped for this study into four: prairies, forests, open woodland, and crops.

- Leaf area index (LAI). Leaf area index maps were derived from MODIS data (Duchemin et al., 2006) at a resolution of $250 \mathrm{~m}$ on days $02 / 11,11 / 11$ and $17 / 11$.

- Digital elevation model. A 250-m digital elevation model of the catchment area was also considered for the processing of airborne data described next.

\section{Methodology}

\subsection{Aircraft data processing}

The retrieval of surface parameters like soil moisture is based on the comparison between simulations and airborne measurements of the surface brightness temperature. For these two brightness temperatures to be comparable a number of processing steps are required, as summarised next.

\subsubsection{Step 1. Ground location of the antenna footprint}

For this step, a regular grid with the antenna directional cosines (function of zenith and azimuth angles in the antenna frame) is projected onto the surface in order to calculate the location and local incidence angle of each grid point (Tenerelli et al., 2008). This step takes into account the orientation of each antenna beam, and the aircraft attitude corresponding to each measurement.

\subsubsection{Step 2. TB simulations at the surface level}

This step is used to retrieve necessary ground information (e.g. land use) at each point of the projected grid. Simulated brightness temperatures of the whole area covered by each antenna are calculated using the SMOS Level 2 breadboards (Kerr et al., 2006) at each grid point.

\subsubsection{Step 3. TB simulations at the antenna level}

For each acquisition, the rotation of the polarisation basis from the surface to the antenna level due to the aircraft movement is calculated, in order to obtain brightness temperatures at the antenna level from brightness temperatures at the surface. For this rotation (Eq. (11) in Waldteufel \& Caudal, 2002), the 3rd and 4th Stokes parameters are assumed to be zero at the surface. Brightness temperatures at the antenna level are then weighted by the antenna gain, and in this way become ready for comparison with the radiometric measurements.

Given the characteristics of the site we considered footprints to be flat. Footprints including altitude variations higher than $5 \mathrm{~m}$ across the $-3 \mathrm{~dB}$ area were discarded. Note that Steps 1 and 3 could be generally neglected for land applications for stable flights (pitch and roll under $2^{\circ}$ ), small antenna apertures (if modelling assumes that all radiation originates in the boresight direction) and homogeneous surfaces. They were included in the processing though to account for the multi-angular signature integrated by large aperture antennas, and for a better radiometric description of heterogeneous areas.

\subsection{L-MEB main equations}

The L-MEB model main equations for soil and vegetation are summarised below. Symbols $p$ and $\theta$ indicate a dependence on polarisation and angle respectively. The soil brightness temperature $T B_{S}(1)$ is obtained from the Fresnel coherent reflectivity $r_{\mathrm{S}, \mathrm{p}}^{*}$ and a set of roughness parameters $H_{\mathrm{R}}$ and $N_{\mathrm{R}, \mathrm{p}}$ for non-smooth surfaces. The soil temperature $T_{\mathrm{S}}(2)$ considered to contribute to the soil emission is a combination of temperatures, deep and near the surface, modified by a factor dependent on the surface soil moisture $(S M)$, and two fixed parameters $w_{0}$ and $b_{w_{0}}$ (default values are $w_{0}=0.3 \mathrm{~m}^{3} \mathrm{~m}^{-3}$ and $b_{w_{0}}=0.3$, Wigneron et. al., 2007).

$$
\begin{aligned}
& T B_{\mathrm{S}, \mathrm{p}, \theta}=\left(1-r_{\mathrm{S}, \mathrm{p}, \theta}^{*} \exp \left(-H_{\mathrm{R}} \cos (\theta)^{N_{\mathrm{R}, \mathrm{p}}}\right)\right) T_{\mathrm{S}}=\left(1-r_{\mathrm{S}, \mathrm{p}, \theta}\right) T_{\mathrm{S}} \\
& T_{\mathrm{S}}=T_{\text {depth }}+\left(T_{\text {sfce }}-T_{\text {depth }}\right)\left(\frac{S M}{w_{0}}\right)^{b_{w_{0}}} .
\end{aligned}
$$

The final equation for the surface brightness temperature $T B$ (3) accounts also for vegetation, and a soil-vegetation composite temperature $T_{\mathrm{GC}}$ described in Wigneron et al. (2007). In this study we considered vegetation and surface temperatures to be equal based on the data availability. Finally, the vegetation parameters in the model are the single scattering albedo $\omega_{\mathrm{p}}$, the transmissivity $\gamma$ and the optical depth parameters $\tau_{\mathrm{NAD}}$ and $t t_{\mathrm{p}}$.

$$
T B_{\mathrm{p}, \theta}=\left(\left(1-\omega_{\mathrm{p}}\right)\left(1-\gamma_{\mathrm{p}, \theta}\right)\left(1+\gamma_{\mathrm{p}, \theta} r_{\mathrm{S}, \mathrm{p}, \theta}\right)+\left(1-r_{\mathrm{S}, \mathrm{p}, \theta}\right) \gamma_{\mathrm{p}, \theta}\right) T_{\mathrm{GC}}
$$

$\gamma_{\mathrm{p}, \theta}=\exp \left(-\tau_{\mathrm{NAD}}\left(\sin ^{2}(\theta)+t \mathrm{t}_{\mathrm{p}} \cos ^{2}(\theta)\right)\right) / \cos (\theta)$.

\subsection{Parameter retrievals}

The retrieval of model parameters and surface properties is based on the optimisation of the L-MEB model when contrasted with measurements as described in Section 3.1. The inversion technique uses a modified least squares cost function (5) with the possibility to 
constrain the retrieved parameters $\left(p_{i}\right)$ and brightness temperatures (measured $T B^{\circ}$, and modelled $T B$ ).

$C_{\mathrm{F}}=\frac{\sum\left(T B_{\theta, \mathrm{p}}^{\circ}-T B_{\theta, \mathrm{p}}\right)^{2}}{\sigma_{T B}^{2}}+\frac{\sum_{i}\left(p_{i}-p_{i}^{\mathrm{ini}}\right)^{2}}{\sigma_{\mathrm{p}}^{2}}$.

In this study retrieved parameters $H_{R}, S M$, and $\tau_{\text {NAD }}$ were allowed to change with variance $\sigma_{\mathrm{p}}^{2}=1$. Such variance is higher than that expected one at the field scale as shown by field measurements, and therefore represents a low constraint on the retrieved parameters. The standard deviation for $T B$ measurements $\sigma_{T B}$ was equal to $1 \mathrm{~K}$.

Either $H_{R}$ and $\tau_{\mathrm{NAD}}$, or $S M$ and $\tau_{\mathrm{NAD}}$ was retrieved from multiangular dual-polarisation PLMR data; for EMIRAD, only two configurations were available (nadir, and $40^{\circ}$ at vertical polarisation), and either direct simulations of the brightness temperature or retrievals of one parameter $\left(\tau_{\mathrm{NAD}}\right)$ were conducted. In the latter case, one optical depth was retrieved from simulations of $T B$ at nadir and at $40^{\circ}$ at vertical polarisation. The initial values for the retrieved parameters were set to $0.1 \mathrm{~m}^{3} \mathrm{~m}^{-3}$ for $S M, 0.1$ for $\tau_{\mathrm{NAD}}$ and 0.1 for $H_{\mathrm{R}}$.

Finally, for the selection of multi-angular TB measurements, the surface was gridded at resolutions between $250-\mathrm{m}$ and $500-\mathrm{m}$ as detailed later in the paper. Footprints with the beam centre included in each cell were used to retrieve parameters that were taken as representative of each cell. Standard deviations of each retrieved parameter were also calculated as part of the optimisation procedure.

\section{Results}

In the soil moisture sampling areas both radiometers values were well above those simulated for a surface with small roughness, moderate biomass, and the measured soil moisture (e.g. $H_{R}=0.1, \tau_{\mathrm{NAD}}=0.15$ ). Both the increased level of $T B$ with respect to a planar surface as well as the low angular ratio between nadir and off-nadir measurements could only be explained in terms of the surface roughness through the roughness parameters $H_{\mathrm{R}}$ and $N_{\mathrm{R}, \mathrm{p}}$ (1). This feature could not be attributed to instrumental errors in the aircraft data, ground instruments, surface temperature, or soil moisture, and was observed at different flying altitudes and both radiometers. The approach presented next aimed at minimising the effect of roughness on soil moisture retrievals using microwave measurements and knowledge of the land use only.

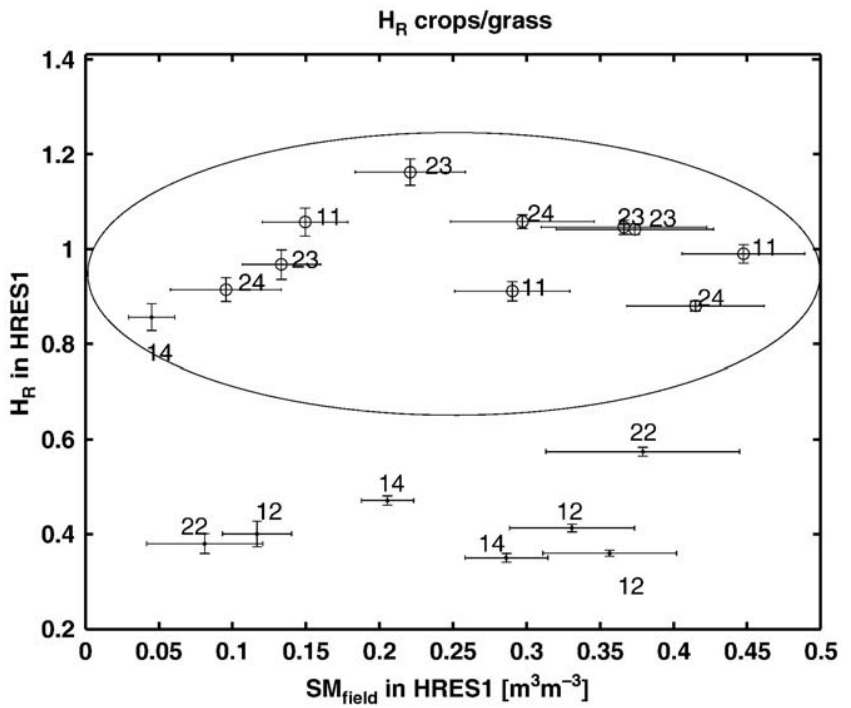

Fig. 2. Surface roughness parameter $H_{\mathrm{R}}$ retrieved over crops (inside ellipse) and grass (outside ellipse) from CT1-PLMR flights in the HRES1 area. Numbers correspond to farms (labels in Table 1) and bars are standard deviations of averaged field soil moisture in the HRES1 area $\left(S M_{\text {field }}, x\right.$ axis) and retrieved roughness $\left(H_{R}, y\right.$ axis) respectively.
Table 3

Results of parameter retrievals.

\begin{tabular}{|c|c|c|c|c|c|c|}
\hline Flight & Area & Roughness & $\begin{array}{l}\text { RMS SM } \\
{\left[\mathrm{m}^{3} \mathrm{~m}^{-3}\right]}\end{array}$ & $R^{2} S M$ & $\begin{array}{l}\text { No. of } \\
\text { cells }\end{array}$ & $\tau_{\mathrm{NAD}}$ \\
\hline \multicolumn{7}{|c|}{ Soil moisture retrievals - crops } \\
\hline \multirow[t]{2}{*}{ CT1-PLMR } & HRES1 & 3-P inversion & $>0.1$ & $<0$ & 12 & 0.14 \\
\hline & & $2-\mathrm{P}, H_{\mathrm{R}}=1.0$ & 0.046 & 0.94 & 12 & 0.13 \\
\hline \multirow[t]{2}{*}{ AT-PLMR } & HRES1 & 3-P inversion & $>0.1$ & 0.50 & 5 & 0.13 \\
\hline & & $2-\mathrm{P}, H_{\mathrm{R}}=1.0$ & 0.044 & 0.68 & 5 & 0.13 \\
\hline \multirow[t]{2}{*}{ CT1-PLMR } & HRES2 & 3-P inversion & $>0.1$ & $<0$ & 20 & 0.12 \\
\hline & & $2-\mathrm{P}, H_{\mathrm{R}}=1.0$ & 0.046 & 0.93 & 20 & 0.13 \\
\hline \multicolumn{7}{|c|}{ Soil moisture retrievals - grass } \\
\hline \multirow[t]{2}{*}{ CT1-PLMR } & HRES1 & 3-P inversion & $>0.1$ & $<0$ & 8 & 0.15 \\
\hline & & $2-\mathrm{P}, H_{\mathrm{R}}=0.4$ & 0.040 & 0.94 & 8 & 0.15 \\
\hline \multirow[t]{2}{*}{ CT1-PLMR } & HRES2 & 3-P inversion & $>0.1$ & $<0$ & 26 & 0.25 \\
\hline & & $2-\mathrm{P}, H_{\mathrm{R}}=0.4$ & 0.034 & 0.96 & 26 & 0.25 \\
\hline \multirow[t]{2}{*}{ CT2-PLMR } & HRES2 & 3-P inversion & $>0.1$ & $<0$ & 18 & 0.24 \\
\hline & & $2-\mathrm{P}, H_{\mathrm{R}}=0.4$ & 0.042 & 0.95 & 18 & 0.25 \\
\hline \multicolumn{7}{|c|}{ Soil moisture retrievals - mixed $\left({ }^{a} H_{R}\right.$ of dominant land use $(L U),{ }^{b} H_{R}$ function of $\left.L U\right)$} \\
\hline \multirow[t]{3}{*}{ AT-PLMR } & HRES2-crop & $2-\mathrm{P},{ }^{\mathrm{a}} H_{\mathrm{R}}$ & 0.059 & 0.94 & 9 & - \\
\hline & & $2-\mathrm{P},{ }^{\mathrm{b}} \mathrm{H}_{\mathrm{R}}$ & 0.046 & 0.98 & 9 & - \\
\hline & $\begin{array}{l}\text { HRES2-open } \\
\text { woodland }\end{array}$ & $2-\mathrm{P}, H_{\mathrm{R}}=0.4$ & 0.026 & 0.70 & 4 & - \\
\hline \multicolumn{7}{|c|}{ TB direct simulations - EMIRAD. ( ${ }^{*}$ see text) } \\
\hline Flight & Area & Roughness & RMS TB $[\mathrm{K}]$ & $R^{2} T B$ & No. of pts & $\tau_{\mathrm{NAD}} *$ \\
\hline AT-EMI & HRES2-crop & $2-\mathrm{P}, H_{\mathrm{R}}=1.0$ & 2.2 & 0.98 & 157 & 0.13 \\
\hline AT-EMI & HRES2-grass & $2-\mathrm{P}, H_{\mathrm{R}}=0.4$ & 1.7 & 0.97 & 87 & $0.08,0.3$ \\
\hline
\end{tabular}

\subsection{Soil emission characterisation}

Estimates of soil parameters were obtained from CT1-PLMR flights (Table 2) in the homogeneous HRES1 areas, where a large number of soil moisture measurements were available (typically above 200). The reference soil moisture for the HRES1 area was the simple average of all soil moisture measurements within that area $\left(S M_{\text {field }}\right)$. As summarised in the Introduction, the selected approach was a two-parameter (2-P) inversion that fixes soil moisture, and estimates simultaneously $H_{\mathrm{R}}$ and the optical depth at nadir $\left(\tau_{\mathrm{NAD}}\right)$ from multi-angular brightness temperatures. In fact, 3-parameter (3-P) inversion tests where $S M, H_{R}$ and $\tau_{\mathrm{NAD}, 3 \mathrm{P}}$ were obtained simultaneously from CT1-PLMR data failed at retrieving $S M$ correctly but provided optical depths comparable to those obtained from the 2-P approach $\left(\tau_{\mathrm{NAD}, 2 \mathrm{P}}\right)$. While the root mean square error (RMSE) between $\tau_{\mathrm{NAD}, 2 \mathrm{P}}$ and $\tau_{\mathrm{NAD}, 3 \mathrm{P}}$ was under 0.04 for grass and crops, the RMSE between $S M_{\text {field }}$ and $S M_{3 P}$ was above $0.2 \mathrm{~m}^{3}$ $\mathrm{m}^{-3}$ whereas errors under $0.05 \mathrm{~m}^{3} \mathrm{~m}^{-3}$ are desirable for satellite products (Walker \& Houser, 2004). These results suggest that 3-P retrievals fail because the inversion returns low soil moisture in rough soils, as for most configurations these surfaces are characterised by high brightness temperature and low angular ratio at a given polarisation. Therefore, roughness needs to be highly constrained in order to obtain good retrievals of soil moisture as found by other studies (Pardé et al., 2004; Wigneron et al., 2007). The 2-P inversion with known SM in the HRES1 area produced very good fits in terms of brightness temperatures (RMSE $<3 \mathrm{~K}, R^{2}>0.95$ ), and clear differences between $H_{R}$ over crops and grass (Fig. 2). Other parameters were $t t_{\mathrm{p}}=1, \omega_{\mathrm{p}}=0, N_{\mathrm{R}, \mathrm{H}}=1$ and $N_{\mathrm{R}, \mathrm{V}}=0$, which resulted from best-fit model simulations conducted farm to farm with ancillary vegetation information (not discussed here). Based on Fig. 2, average values of $H_{\mathrm{R}}$ over crops and grass were obtained.

$H_{\mathrm{R}}(\mathrm{crop})=1.0(\sigma=0.2)$

$H_{\mathrm{R}}($ grass $)=0.4(\sigma=0.2)$

Note that at Roscommon farm ('14' in Fig. 2) large roughness was obtained for rather dry soil $\left(0.04 \mathrm{~m}^{3} \mathrm{~m}^{-3}\right)$ as well as very low optical 
depth compared to previous days. Because field and satellite measurements indicated no significant vegetation changes, we did not include that point in the averaged $H_{R}(6)$. We also determined that differences in the averaged roughness parameter $H_{R}$ were negligible between using a small standard deviation on the optical depth $\left(\sigma_{\tau}=0.01\right.$ in Eq. (5)), or a large one $\left(\sigma_{\tau}=1\right)$.

The error in soil moisture retrievals in the roughness calibration areas (HRES1) was RMSE $=0.040 \mathrm{~m}^{3} \mathrm{~m}^{-3}\left(R^{2}=0.94\right)$ for grass, and RMSE $=0.046\left(R^{2}=0.94\right) \mathrm{m}^{3} \mathrm{~m}^{-3}$ for crops (Table 3), following a 2-P inversion of SM and $\tau_{\text {NAD }}$ and the constant roughness values in Eq. (6).

The same roughness fit was applied to PLMR along-track data over crops (AT-PLMR, Table 2) in the HRES1 areas. These flights were obtained at a higher altitude ( $250 \mathrm{~m}$ nominal resolution), and the accuracy of the soil moisture retrievals was RMSE $=0.044 \mathrm{~m}^{3} \mathrm{~m}^{-3}$ $\left(R^{2}=0.68\right)$.

Alternative methods to determine surface roughness were also explored, such as "field-to-field" 1-parameter (1-P) retrievals of $H_{R}$ with known soil moisture, and optical depth estimates based on field measurements of vegetation water content and satellite-derived LAI. Results of the 1-P inversion of $H_{\mathrm{R}}$ led to mean roughness $H_{\mathrm{R}}=1.1$ for

\section{a}

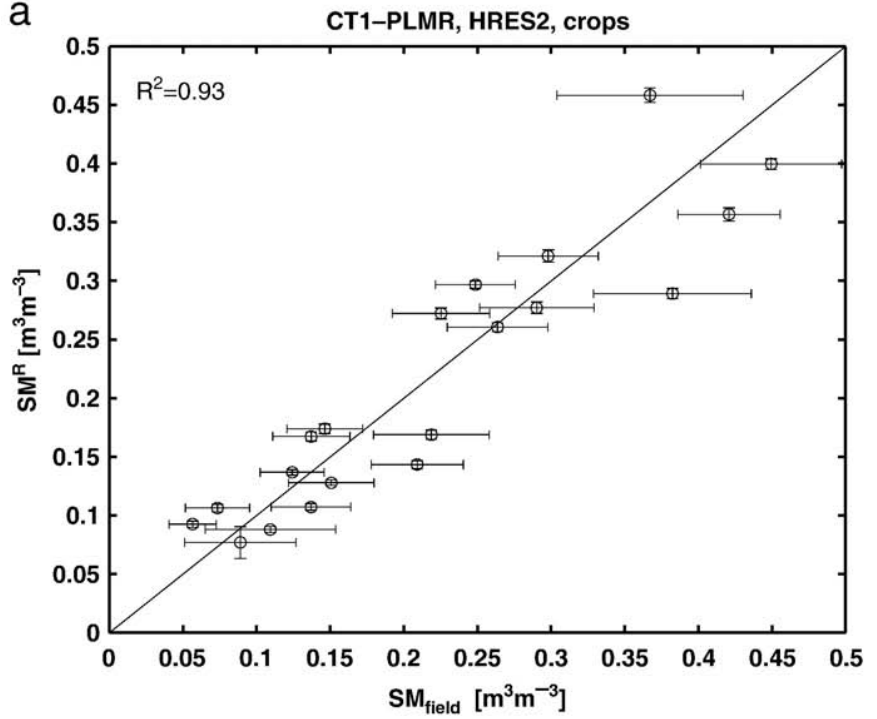

b

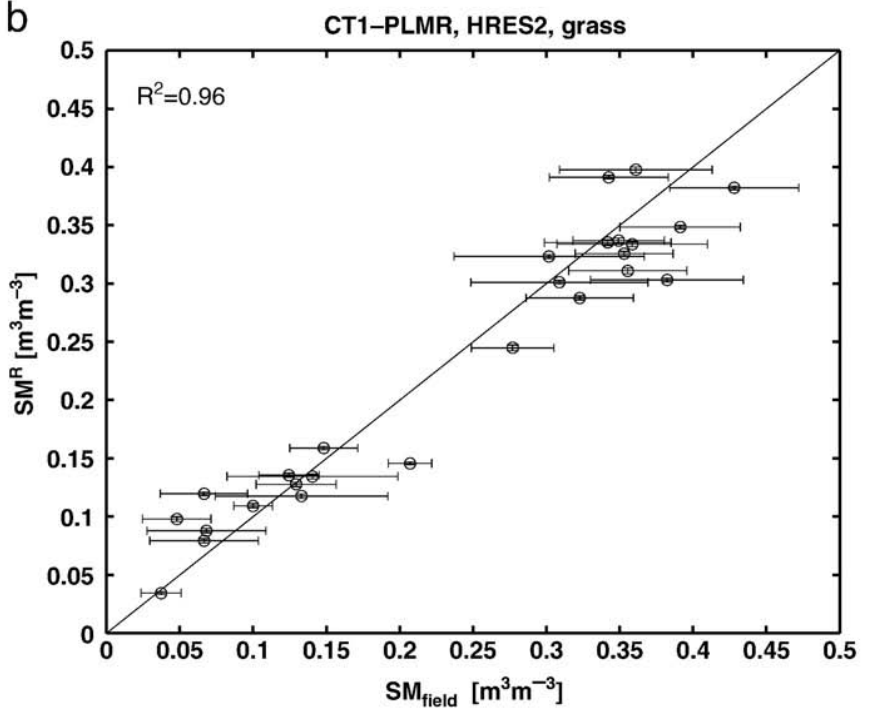

Fig. 3. (a) Soil moisture retrievals $\left(S M^{\mathrm{R}}\right)$ over 'pure' crops, and 'pure' grass (b) from CT1PLMR flights in the HRES2 area based on a 2-P inversion $\left(S M^{R}, \tau_{N A D}\right)$ with the roughness fit in Eq. (6). Bars indicate the standard deviation of the field soil moisture ( $\left.S M_{\text {field }}\right)$ and the retrieved soil moisture $\left(S M^{\mathrm{R}}\right)$.
Table 4

L-MEB parameters used for retrievals.

\begin{tabular}{lllllll}
\hline Land use & $H_{\mathrm{R}}$ & $N_{\mathrm{R}, \mathrm{H}}$ & $N_{\mathrm{R}, \mathrm{V}}$ & $\omega_{\mathrm{H}}$ & $\omega_{\mathrm{V}}$ & $t t_{\mathrm{p}}$ \\
\hline Crop & 1.0 & 1 & 0 & 0 & 0 & 1 \\
Grass & 0.4 & 1 & 0 & 0 & 0 & 1 \\
Open woodland & 0.4 & 1 & 0 & 0 & 0.09 & 1 \\
\hline
\end{tabular}

crops, and mean $H_{\mathrm{R}}=0.5$ for grass for $\tau_{\mathrm{NAD}}=0.06 \cdot \mathrm{LAI}$, with 0.06 being an optimised parameter. These roughness values are close to those derived from the 2-P approach in Eq. (6), the main difference between the two being a higher sensitivity of $H_{R}$ to $S M$ observed in the 1-P estimates of $H_{R}$ for crops. For example, in the 1-P case the roughness variation between dry $\left(0.05 \mathrm{~m}^{3} \mathrm{~m}^{-3}\right)$ and wet $\left(0.40 \mathrm{~m}^{3} \mathrm{~m}^{-3}\right)$ soils was approximately $\Delta H_{R}=0.4$ for crops (mean $H_{R}=1.1$ ), and the correlation between $H_{\mathrm{R}}$ and $S M$ was $R^{2}=0.54$. However, applying a constant roughness correction was explored further as a way to retrieve soil moisture in areas of unknown roughness and unknown optical depth as described next.

\subsection{Soil moisture retrievals in the HRES2 areas}

Soil moisture retrievals beyond the calibration area were investigated from low altitude flights (CT1-PLMR), and from higher altitude flights (CT2-PLMR, AT-PLMR and AT-EMIRAD). Reference soil moisture for validation in this region (HRES2) was obtained at either 250-m cells (CT1-PLMR, AT-PLMR, AT-EMIRAD flights) or 500-m cells (CT2-PLMR). The size of the grids was selected according to the size of the footprints, and to ensure multi-angular measurements inside each cell. Within each of these cells, one reference soil moisture was obtained from averaging field soil moisture data, and only cells with more than 20 soil moisture sampling points were compared to retrievals. Therefore, each cell had a corresponding retrieved soil moisture $\left(S M^{R}\right)$ obtained from multi-angular $T B$ measurements centred in the cell, and obtained concurrently to the optical depth $\tau_{\mathrm{NAD}}$ (Figs. 3 and 5). Table 3 summarises the inversion results following this approach, i.e. 2-P inversions of $S M$ and $\tau_{\mathrm{NAD}}$ with the L-MEB parameters summarised in Table 4. Table 3 also shows results of a 3-P inversion ( $\left.S M, \tau_{\mathrm{NAD}}, H_{\mathrm{R}}\right)$ for comparison. Results for crops, grass and mixed areas are discussed next in detail.

\subsubsection{Crops}

Soil moisture retrievals over crops were conducted in 20 cells (including several days) where the crop fraction covered by the footprints was higher than 95\%, in order to analyse 'pure' pixels (Fig. 3a). Using the roughness fits in Eq. (6) the accuracy in the soil moisture retrievals from CT1-PLMR data was high $\left(\right.$ RMSE $=0.046 \mathrm{~m}^{3} \mathrm{~m}^{-3}$ ), showing that the roughness relation derived from high-resolution flights was still valid outside the calibration area.

As for flights in the HRES1 area, poor correlation $\left(R^{2}=0.3\right)$ was found between $\tau_{\text {NAD }}$ and estimates of LAI based on three MODIS images, the average bias being equivalent to $L A I=1 \mathrm{~m}^{2} \mathrm{~m}^{-2}$ for $\tau_{\mathrm{NAD}}=0.06 \cdot L A I$. However, we found that this is not a limitation for the accuracy of the soil moisture product. For comparison, note that results of 1-P inversions of soil moisture with optimised optical depth $\left(\tau_{\mathrm{NAD}}=0.06 \cdot L A I\right)$ had a RMSE $=0.041 \mathrm{~m}^{3} \mathrm{~m}^{-3} \cdot 1-\mathrm{P}$ inversions used a roughness fit obtained from individual $H_{R}$ retrievals in areas with known soil moisture $\left(H_{\mathrm{R}}=1.4-1.1 \cdot S M, R^{2}=0.54\right)$.

PLMR-based results were then compared to AT-EMIRAD flights $\left(T B_{0, \mathrm{H}}, T B_{0, \mathrm{~V}}\right.$, and $\left.T B_{40, \mathrm{~V}}\right)$ through direct modelling of the brightness temperature in the HRES2 area (Fig. 4a). Direct simulations for these three configurations covered three different days and included three crop farms ( $S M$ range from $0.13 \mathrm{~m}^{3} \mathrm{~m}^{-3}$ to $0.29 \mathrm{~m}^{3} \mathrm{~m}^{-3}$ ). For these simulations a value of $\tau_{\mathrm{NAD}}=0.13$ was used as derived from the PLMR data set (Table 3), mean soil moisture values measured in the HRES2 area, and the roughness fit in Eq. (6). For EMIRAD flights we used the 

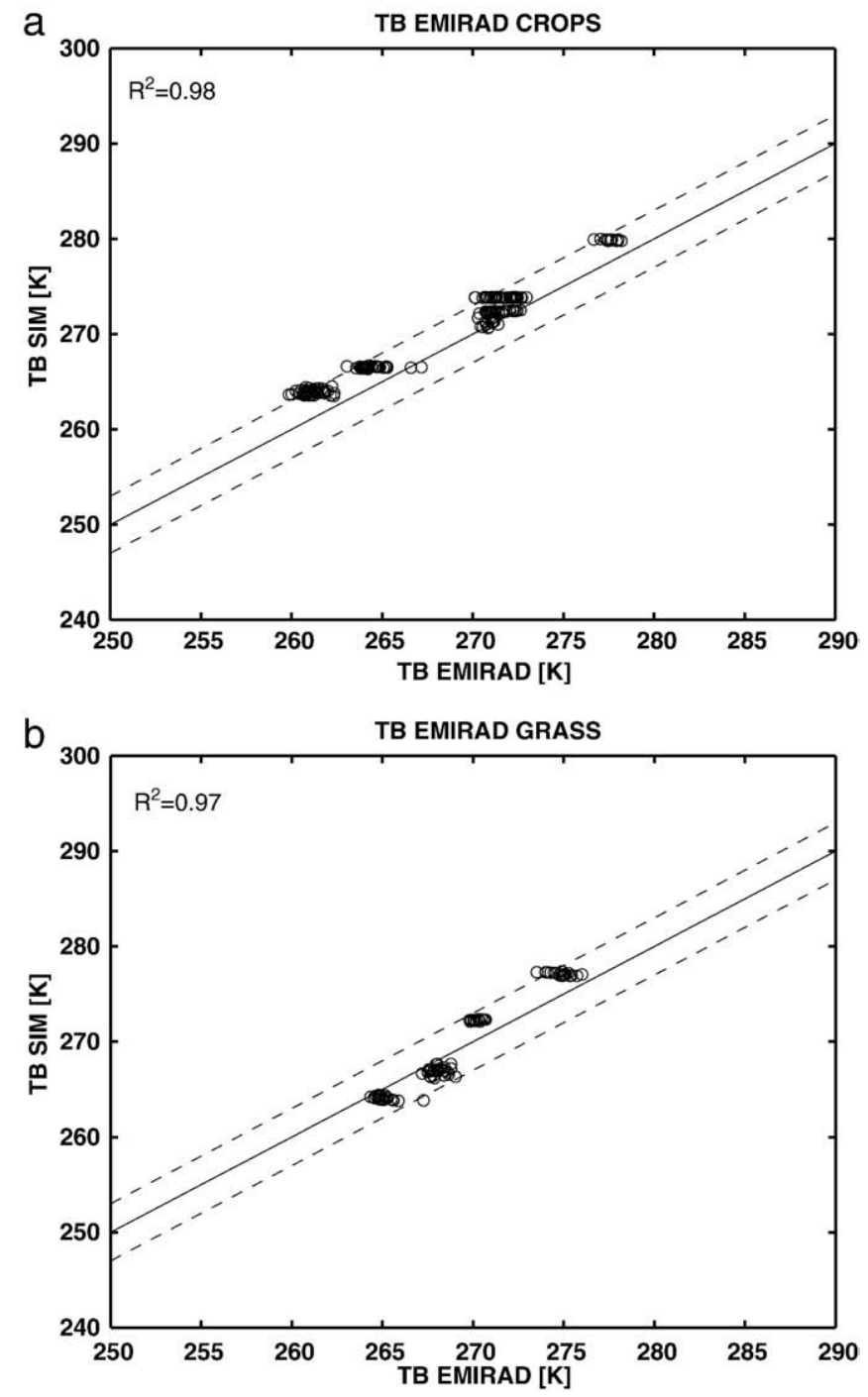

Fig. 4. Comparison between AT-EMIRAD measurements $\left(T B_{0, \mathrm{H}}, T B_{0, \mathrm{~V}}, T B_{40, \mathrm{~V}}\right)$ and simulations of the brightness temperature for crops (a), and grass (b) based on PLMRderived roughness (6). Line 1:1 (solid), and $+/-3 \mathrm{~K}$ (dashed).

surface infrared temperature onboard the aircraft as a proxy for $T_{\text {surf }}$ in Eq. (2). Thermal infrared measurements had a standard deviation lower than $1 \mathrm{~K}$ across each farm, and therefore a constant value was used for the nadir and off-nadir simulations. Based on this approach, the RMSE between simulated and measured AT-EMIRAD brightness temperatures was $2.2 \mathrm{~K}\left(R^{2}=0.98,157\right.$ footprints), including simulations at the Illogan farm that were not considered previously for the roughness calibration from PLMR data.

\subsubsection{Grass}

Soil moisture retrievals from CT1-PLMR flights over grass were possible in 26 cells across three different farms. The same 2-P approach as for crops was followed, and soil moisture could be estimated with an accuracy of $0.034 \mathrm{~m}^{3} \mathrm{~m}^{-3}$ (Fig. 3b). In addition, CT2-PLMR flights over 'pure grass' were analysed. At this resolution (250 m nadir) estimates were still good (RMSE $=0.042 \mathrm{~m}^{3} \mathrm{~m}^{-3}$, Fig. 5) despite the increased cell size (500-m, in order to obtain multiangular footprints).

In terms of optical depths obtained from CT1-PLMR flights we observed differences between the farms, with mean $\tau_{\mathrm{NAD}} \sim 0.28$ at Stanley and Midlothian, and mean $\tau_{\mathrm{NAD}} \sim 0.11$ at Roscommon where the vegetation biomass was significantly shorter than at other farms in the HRES2 area.
These optical depth values were used for comparison with ATEMIRAD flights over the same farms (Fig. 4b). In this exercise $\tau_{\text {NAD }}$ was retrieved for comparison with previous estimates obtained from PLMR data. Very good agreement was found between measured and simulated TBS at the Stanley farm (RMSE $=1.7 \mathrm{~K}, R^{2}=0.98$ ), where the retrieved $\tau_{\mathrm{NAD}}$ was 0.30 . At Roscommon, the retrieved $\tau_{\mathrm{NAD}}$ was 0.08 (RMSE $=1.8 \mathrm{~K})$, which is consistent with the low values obtained from PLMR data at this farm too. This agreement in optical depths for fixed roughness and soil moisture indicates that measurements from the two sensors were similar. Results at Midlothian were less conclusive, as soil moisture measurements in the densely sampled areas were highly variable $(\sigma(S M) / \operatorname{mean}(S M) \sim 1)$ on the day of EMIRAD flights. Outside the dense sampling region retrievals of $\tau_{\mathrm{NAD}}$ varied between 0.2 and 0.3 (RMSE $<1 \mathrm{~K}$ ), but given the smaller number of soil moisture points these have not been included in Fig. 3b.

Based on positive results of five of the six farms with AT-EMIRAD flights we consider the data from the two sensors to be in reasonable agreement. Also, the fact that roughness correction appears appropriate at different times of the day (early in the morning for EMIRAD, and up to the early afternoon for PLMR) indicates that surface temperature does not have a significant impact on the roughness correction.

\subsubsection{Land use mixing}

Finally, footprints including different land uses were analysed. For this exercise PLMR along-track flights were most appropriate. The retrieved parameters were obtained for $250-\mathrm{m}$ cells, and the mixing factor was taken as a cell-averaged value of the land use fractions of individual footprints falling into each cell. Cells at Midlothian and Merriwa Park satisfied the requirements to include multi-angular measurements and multiple land uses (crop-grass mixtures, or grassopen woodland mixtures). An illustration of these cells is shown in Fig. 6 together with an aerial photograph of a woodland area at Midlothian.

At Merriwa Park, three cells at the boundary of crop and grass fields were examined across four different days. Note that not all flights provided $T B$ measurements of all cells, although each cell could be monitored at least twice. In terms of mixing, the crop fraction varied between approximately $20 \%$ and $60 \%$ in the antenna $-3 \mathrm{~dB}$ region (Table 5). At Midlothian, only areas with a small fraction of open woodland were supported by enough soil moisture sampling, and four cells were selected for the study. The woodland fraction varied between $7 \%$ and $30 \%$ (Table 5 ).

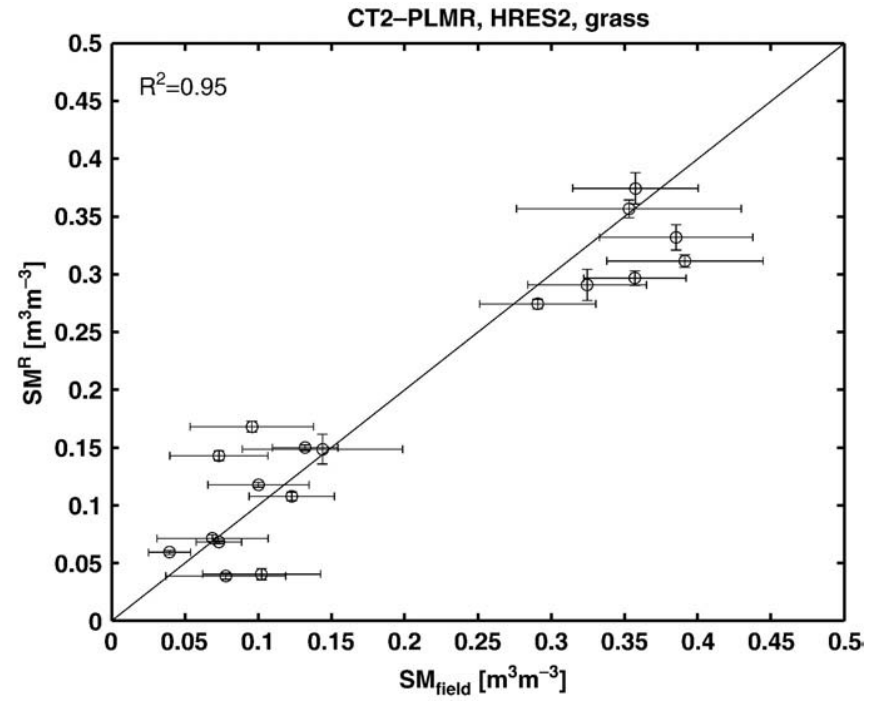

Fig. 5. Soil moisture retrievals from CT2-PLMR flights over grass in the HRES2 area based on a 2-P inversion $\left(S M^{R}, \tau_{N A D}\right)$ with the roughness fit in Eq. (6). Bars indicate the standard deviation of the measured field soil moisture $\left(S M_{\text {field }}\right)$ and the retrieved soil moisture $\left(S M^{\mathrm{R}}\right)$. 
a

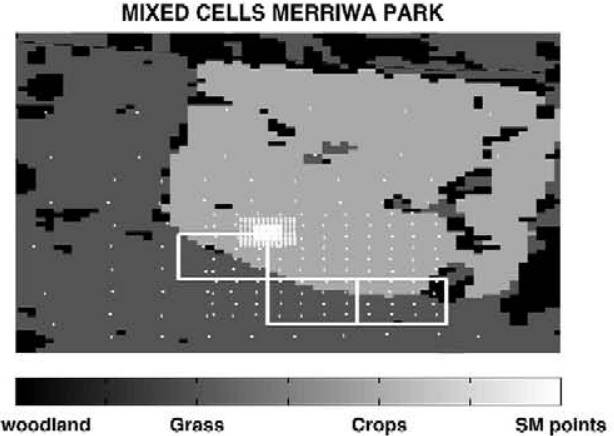

b

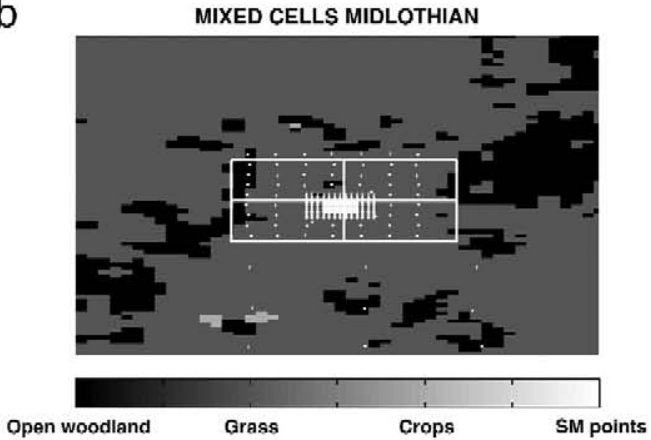

C

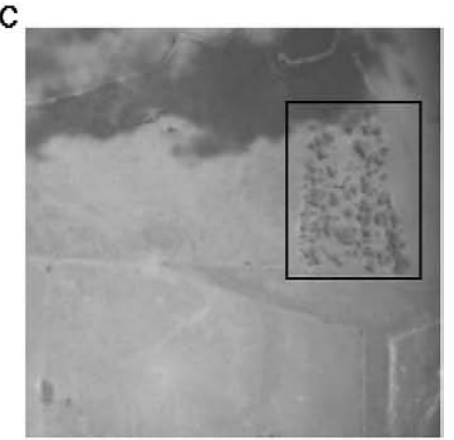

Fig. 6. Selected cells (white rectangles) for retrievals over mixed land uses. (a) Merriwa Park (crops and grass), (b) Midlothian (grass and open woodland), and (c) Example of an open woodland area (rectangle) inside a grass plot at Midlothian (dark patches are clouds).

The same approach based on a 2-P inversion of soil moisture and $\tau_{\text {NAD }}$ was followed, and the roughness distribution within the footprint was considered for the simulations. More precisely, the roughness values corresponding to each antenna grid point were chosen based on the land use, this is $H_{R}=1$ for crops, and $H_{R}=0.4$ for grass and open woodland.

Retrievals in cells including crops and grass at Merriwa Park (Fig. 6a) showed that the mean RMSE between the field soil moisture and the retrieved one was $0.046 \mathrm{~m}^{3} \mathrm{~m}^{-3}\left(R^{2}=0.98\right)$ when the roughness of each land use included in the footprint was considered to compute the brightness temperature (Table 5). The error was $0.059 \mathrm{~m}^{3} \mathrm{~m}^{-3}\left(R^{2}=0.94\right)$ when the roughness of the dominant land use (crop or prairie) was used instead.

For woodland patches in grass fields (Fig. 6b, c) the same roughness correction as that of grass was assumed, and vertical scattering albedo $\omega_{\mathrm{V}}$ was 0.09 ('default SMOS Level 2'). Soil moisture retrievals in these cells were close to the field measurements with RMSE $=0.026 \mathrm{~m}^{3} \mathrm{~m}^{-3}$ $\left(R^{2}=0.70\right)$. Because the fraction of forest vegetation in open woodland areas was small, using the same roughness correction for grass and open woodland agreed with the observations. These results are positive as they provide good prospects for retrievals in mixed land uses, and highlight the importance of including appropriate roughness corrections in the simulation of mixed footprints.

\section{Summary and discussion}

This paper investigated L-band measurements over grass and crops obtained from two airborne-based L-band radiometers (PLMR and EMIRAD) during the COSMOS/NAFE'05 campaign in south-east Australia. The main objective of the study was to evaluate the performance of the microwave radiative transfer model which sits at the core of ESA's SMOS soil moisture algorithm, and to point out differences between modelling outputs and measurements. In this

Table 5

Summary of 250-m cells used to analyse retrievals in mixed pixels from AT-PLMR data (areas covered by clouds/no data taken as grass).

\begin{tabular}{|c|c|c|c|c|c|c|}
\hline Farm/DOY & $\%$ open woodland & $\%$ grass & $\%$ crops & $S M^{R}$ & $S M_{\text {field }}$ & $\begin{array}{l}\text { RMSE } \\
\text { TB [K] }\end{array}$ \\
\hline Midlothian/315 & 7 & 93 & 0 & 0.36 & $0.38(0.10)$ & 1.9 \\
\hline Midlothian/315 & 11 & 89 & 0 & 0.37 & $0.36(0.11)$ & 1.7 \\
\hline Midlothian/315 & 16 & 84 & 0 & 0.35 & $0.31(0.12)$ & 1.6 \\
\hline Midlothian/315 & 30 & 70 & 0 & 0.31 & $0.30(0.13)$ & 3.2 \\
\hline Merriwa Park/304 & 5 & 64 & 31 & 0.32 & $0.35(0.13)$ & 4.4 \\
\hline Merriwa Park/311 & 1 & 77 & 22 & 0.33 & $0.39(0.04)$ & 3.1 \\
\hline Merriwa Park/311 & 6 & 60 & 34 & 0.32 & $0.36(0.08)$ & 4.7 \\
\hline Merriwa Park/311 & 4 & 68 & 28 & 0.36 & $0.41(0.08)$ & 3.1 \\
\hline Merriwa Park/320 & 2 & 46 & 52 & 0.15 & $0.22(0.07)$ & 1.9 \\
\hline Merriwa Park/325 & 1 & 77 & 22 & 0.16 & $0.17(0.06)$ & 2.2 \\
\hline Merriwa Park/325 & 2 & 39 & 59 & 0.13 & $0.13(0.04)$ & 2.2 \\
\hline
\end{tabular}

Superscript 'R' is for retrieved. DOY stands for Day of Year. respect, the analysis of the COSMOS/NAFE'05 data set showed that calibration of the surface roughness is key for successful soil moisture retrievals at L-band, at least at the investigated spatial resolutions (60-375 m nadir), and an approach to overcome the limitations of unknown roughness was presented. Many studies report site-specific calibrations of surface roughness, but we still lack a clear understanding of the physical meaning of such roughness, and how it could be applied globally to minimise its effect on soil moisture retrievals. The approach developed uses a two-step two-parameter inversion of the radiative transfer model (L-MEB). This approach was tested from ground-based L-band measurements at high resolution before (Saleh et al., 2007b), but not at larger scales as observed from an aircraft, and over different types of surfaces.

First, the L-MEB main roughness parameter $H_{\mathrm{R}}$ and the optical depth $\tau_{\text {NAD }}$ were obtained simultaneously in small areas of known soil moisture using multi-angular radiometric brightness temperatures at $\mathrm{H}$ and $\mathrm{V}$ polarisations (PLMR), and a roughness correction based on land use only was obtained. Then, simultaneous soil moisture SM and optical depth $\tau_{\text {NAD }}$ retrievals with a high constraint on roughness (effectively a 2-P inversion) were conducted beyond the calibration area, at different resolutions (60 m-250 m), and viewing configurations (across-track, along-track). The soil roughness correction was also used to simulate measurements of the second radiometer (EMIRAD) as a mean of validation, with errors in the simulated brightness temperatures around $2 \mathrm{~K}$. Globally, soil moisture estimates were obtained with errors ranging between $0.03 \mathrm{~m}^{3} \mathrm{~m}^{-3}$ and $0.05 \mathrm{~m}^{3}$ $\mathrm{m}^{-3}$ compared to the mean field soil moisture, and included 'pure crop' and 'pure grass' areas, as well as mixed areas of crop and grass, and grass and open woodland.

The main emphasis of the two-step two-parameter inversion approach is in reducing the influence of surface roughness to retrieve soil moisture from L-band data. More studies though are needed to evaluate the options for obtaining vegetation products from this approach. The fact that a low correlation between retrieved optical depths and leaf area index was found could be linked to using a constant roughness correction, as soil roughness has been shown to decrease with soil moisture in some studies. Soil moisture has an impact on the wave penetration depth, and roughness estimates could be affected by the thickness of the sensing layer, though no conclusions on this matter have been found yet. Nevertheless, the main interest of the method lies in the opportunity for the calibration of surface roughness should it appear crucial at satellite scales, as only land use knowledge would be required.

From an operational perspective, two steps towards calibrating roughness could be envisaged, first at the instrumented mission's validation sites distributed across the world, then elsewhere. At the validation sites, two-parameter retrievals $\left(H_{\mathrm{R}}\right.$ and $\left.\tau_{\mathrm{NAD}}\right)$ would provide the first estimates of roughness at the scale of a satellite footprint for the whole soil moisture range. In parallel, time series of brightness temperatures could be used to detect very dry and very wet soil to 
analyse roughness estimates obtained for extreme soil moisture conditions only. The interest of such experiment would be in investigating the extension of the calibration approach to noninstrumented areas, where very dry or very wet soil conditions could be determined either from brightness temperature time series, or change-detection techniques applied to microwave active measurements (Wagner et al., 1999). In this way, studies pursuing a global correction of roughness based on the land use could be explored. Finally, the continuation of field experiments to improve our understanding of the physical basis for the emission of rough soils at L-band is essential, and upcoming airborne experiments will contribute to better understand the role of scaling in surface roughness.

\section{Acknowledgments}

The authors would like to acknowledge the COSMOS and NAFE'05 teams as well as J. Tenerelli and N. Reul (Boost/Ifremer) for sharing their processing tool TRAP (The Terrestrial Radiometry Analysis Package, version 0.1). This study was conducted under the European Space Agency contract RFQ-3-11801/06/NL/FF and the CNES/TOSCA program.

\section{References}

Choudhury, B. J., Schmugge, T. J., Chang, A., \& Newton, R. W. (1979). Effect of surface roughness on the microwave emission from soils. Journal of Geophysical Research, $84,5699-5706$

Delwart, S., Bouzinac, C., Wursteisen, P., Berger, M., Drinkwater, M., Martin-Neira, M. et al. (2008). SMOS validation and the COSMOS campaigns. IEEE Transactions on Geoscience and Remote Sensing, 46, 695-704.

Duchemin, B., Hadria, R., Er-Raki, S., Boulet, G., Maisongrande, P., Chehbouni, A., et al (2006). Monitoring wheat phenology and irrigation in Central Morocco: On the use of relationship between evapotranspiration, crops coefficients, leaf area index and remotely-sensed vegetation indices. Agricultural Water Management, 79, 1-27.

Escorihuela, M. J., Kerr, Y. H., de Rosnay, P., Wigneron, J. P., Calvet, J. C., \& Lemaitre, F. (2007). A simple model of the bare soil microwave emission at L-band. IEEE Transactions on Geoscience and Remote Sensing, 45, 1978-1987.

Kerr, Y. H., Waldteufel, P., Richaume, P., Davenport, I., Ferrazzoli, P., \& Wigneron, J. P. (2006). SMOS level 2 processor soil moisture algorithm theoretical basis document (ATBD). SM-ESL (CBSA), CESBIO, Toulouse, SO-TN-ESL-SM-GS-0001, V5.a, 15/03/ 2006 .
Mo, T., \& Schmugge, T. J. (1987). A parameterization of the effect of surface roughness on microwave emission. IEEE Transactions on Geoscience and Remote Sensing, 25, 47-54.

Panciera, R., Walker, J. P., Kalma, J. D., Kim, E. J., Hacker, J. M., Merlin, O., et al. (2008). The NAFE'05/CoSMOS data set: Toward SMOS soil moisture retrieval, downscaling, and assimilation. IEEE Transactions on Geoscience and Remote Sensing, 46, 736-745.

Panciera, R., Walker, P. J., Kalma, J. D., Kim, E. J., Saleh, K., \& Wigneron, J. P. (2009). Evaluation of the SMOS L-MEB passive microwave soil moisture retrieval algorithm. Remote Sensing of Environment, 113, 435-444.

Pardé, M. Wigneron, J. P. Waldteufel, P. Kerr, Y. H., Chanzy, A., Schmidl, S., et al. (2004). $\mathrm{N}$-parameter retrievals from L-band microwave observations acquired over a variety of crop fields. IEEE Transactions on Geoscience and Remote Sensing, 42, 1168-1178.

Pellarin, T., Kerr, Y. H., \& Wigneron, J. P. (2006). Global simulation of brightness temperature at 6.6 and $10.7 \mathrm{GHz}$ over land based on SMMR data set analysis. IEEE Transactions on Geoscience and Remote Sensing, 44, 2492-2505.

Rotbøll, R., Søbjærg, S. S., \& Skou, N. (2007). A novel L-band polarimetric radiometer featuring subharmonic sampling. Radio Science. doi:10.1029/2002RS002666.

Rudiger, C., Hancock, G. R., Hemakumara, H. M., Jacobs, B., Kalma, J. D., Martinez, C., et al. 2007). The Goulburn River experimental catchment data set. Water Resources Research, 43, W10403. doi:10.1029/2006WR005837.

Saleh, K., Kerr, Y. H., Boulet, G., Maisongrande, P., de Rosnay, P., Floricioiu, D., et al. (2007). The CoSMOS L-band experiment in Southeast Australia, Geoscience and Remote Sensing Symposium, 2007. IGARSS 2007. IEEE International (pp. 3948-3951).

Saleh, K. Wigneron, J. P., Waldteufel, P., de Rosnay, P. Schwank, M. Calvet, J. C., et al. (2007). Estimates of surface soil moisture under grass covers using L-band radiometry. Remote Sensing of Environment, 109, 42-53.

Tenerelli, J. E., Reul, N., Mouche, A. A., \& Chapron, B. (2008). Earth-viewing L-band radiometer sensing of sea surface scattered celestial sky radiation-Part I: General characteristics. IEEE Transactions on Geoscience and Remote Sensing, 46, 659-674.

Wagner, W., Lemoine, G., \& Rott, A. (1999). Method for estimating soil moisture from ERS scatterometer and soil data. Remote Sensing of Environment, 70, 191-207.

Waldteufel, P., \& Caudal, G. (2002). About off-axis radiometric polarimetric measurements. IEEE Transactions on Geoscience and Remote Sensing 40, 1435-1439.

Walker, J. P. \& Houser, P. R. (2004). Requirements of a global near-surface soil moisture satellite mission: Accuracy, repeat time, and spatial resolution. Advances in water resources, 27, 785-801.

Wang, J. R., O'Neill, P. E., Jackson, T. J., \& Engman, E. T. (1983). Multi-frequency measurements of the effects of soil moisture, soil texture, and surface roughness. IEEE Transactions on Geoscience and Remote Sensing, 21, 44-51.

Wigneron, J. P., Kerr, Y. H., Waldteufel, P., Saleh, K., Escorihuela, M. J., Richaume, P., et al. (2007). L-band Microwave Emission of the Biosphere (L-MEB) model: Description and calibration against experimental data sets over crop fields. Remote Sensing of Environment, 107, 639-655

Wigneron, J. P., Laguerre, L., \& Kerr, Y. H. (2001). A simple parameterization of the L-band microwave emission from rough agricultural soils. IEEE Transactions on Geoscience and Remote Sensing, 39, 1697-1707. 